\title{
Introduction to: the euro at twenty
}

\author{
Laura Alfaro $^{1} \cdot$ Paul R. Bergin ${ }^{2}$
}

Published online: 27 November 2018

(c) Kiel Institute 2018

RESOLVED to achieve the strengthening and the convergence of their economies and to establish and economic and monetary union including, in accordance with the provisions of this Treaty, a single and stable currency,

\section{Treaty on European Union (The Maastricht Treaty)}

January 1, 2019 marks 20 years since the introduction of the euro. This anniversary presents an opportunity to reflect on lessons learned from the first 20 years of EMU in Europe, and consider prospects for the future. The last few years have demonstrated the strains possible when multiple countries engage together in the bold venture of monetary union. The editors of Review of World Economics decided to invite several prominent thinkers to offer their insights, regarding what they believe was the biggest surprise from the euro's first 20 years, and what is the biggest challenge for next 20 years.

Our four commenters are renowned leaders and thinkers, chosen because they represent a range of perspectives, with both policy and academic backgrounds. They also encompass a range of geographic perspectives, including French, German and even American backgrounds.

Jean-Claude Trichet had an up-close perspective on the early development of the euro as an active participant, as he was President of the European Central Bank November 2003-October 2011. Currently he is honorary chairman of the Group of Thirty (Washington) and chairman of the Board of Directors of Bruegel Institute, among many other engagements and honors.

Claudia Buch currently serves as Vice-President of the Deutsche Bundesbank since 2014. She also bridges the academic and policy worlds as a former Professor of Economics at the University of Tübingen (2004-2013), and president of Halle Institute for Economic Research (2013-2014). She publishes widely in international journals on the topics of banking and financial market integration. Benjamin

Paul R. Bergin

prbergin@ucdavis.edu

Laura Alfaro

lalfaro@hbs.edu

1 Harvard Business School, Harvard University, Morgan Hall 461, Soldiers Field, Boston, MA 02163, USA

2 University of California at Davis, One Shields Ave., Davis, CA 95616, USA 
Weigert is the Director General of Financial Stability at the Deutsche Bundesbank, and writes on topics of macroeconomic policy.

Barry Eichengreen has been a distinguished academic voice in debates regarding the euro, from the time before its introduction, right up to the present. He is a Professor of Economics and Political Science at the University of California, Berkeley, and a fellow of the American Academy of Arts and Sciences. He is the author of 23 books, many on international financial arrangements, including an early book on European monetary integration.

Charles Wyplosz is Professor of International Economics at the Graduate Institute in Geneva and Director of the International Center of Monetary and Banking Studies. He has published 17 books and countless academic articles, covering the introduction the euro as well as recent challenges to its stability. He is also a frequent commentator in the broader non-academic media, interpreting recent international financial developments.

The essays draw contrasting conclusions regarding appraisals and prescriptions. The two essays from a purely academic perspective tend to focus on the recent strains to the system, and are guarded about prospects for the euro's future, though they characterize the main challenge somewhat differently from each other. Eichengreen (2019) identifies a range of needed reforms, and expresses some skepticism whether the current reform effort will be enough to prepare the euro to withstand the next crisis. Wyplosz (2019) uses his essay to highlight what he argues is an underappreciated shortcoming in a monetary union of multiple countries, the limitations implicit on central bank independence.

In contrast, the two essays from authors associated with policy-making institutions are more sanguine, though in differing ways and differing degrees. Trichet (2019) pushes back against what he sees as a pessimistic bias among academic discussion of the euro, which misses the bigger picture of the successes of the monetary union in terms of credibility, adaptability and economic growth. Buch and Weigert (2019) readily acknowledge recent strains under the financial crisis, but view them as mandate to undertake reforms to strengthen the design of the system. The remedies of the two essays also differ fundamentally, in that Trichet points to the need for deeper international integration and the evolution of institutions over time. In contrast to the loss of national sovereignty implied by deeper integration, Buch and Weigert emphasize a need to expand rules to help prevent future crises, in particular interpreting the need for macroprudential policy as an expansion of the long-standing principle of fiscal discipline to cover private as well as public sector finance.

\section{References}

Buch, C.M., \& Weigert, B. (2019). Macroprudential policy in a currency union. Review of World Economics. https://doi.org/10.1007/s10290-018-0332-6.

Eichengreen, B. (2019). The euro after Meseberg. Review of World Economics. https://doi.org/10.1007/ s10290-018-0329-1. 
Trichet, J.-C. (2019). The euro after 20 years is a historic success: A powerful encouragement for further European reforms and achievements. Review of World Economics. https://doi.org/10.1007/s1029 0-018-0335-3.

Wyplosz, C. (2019). Limits to the independence of the ECB. Review of World Economics. https://doi. org/10.1007/s10290-018-0328-2. 